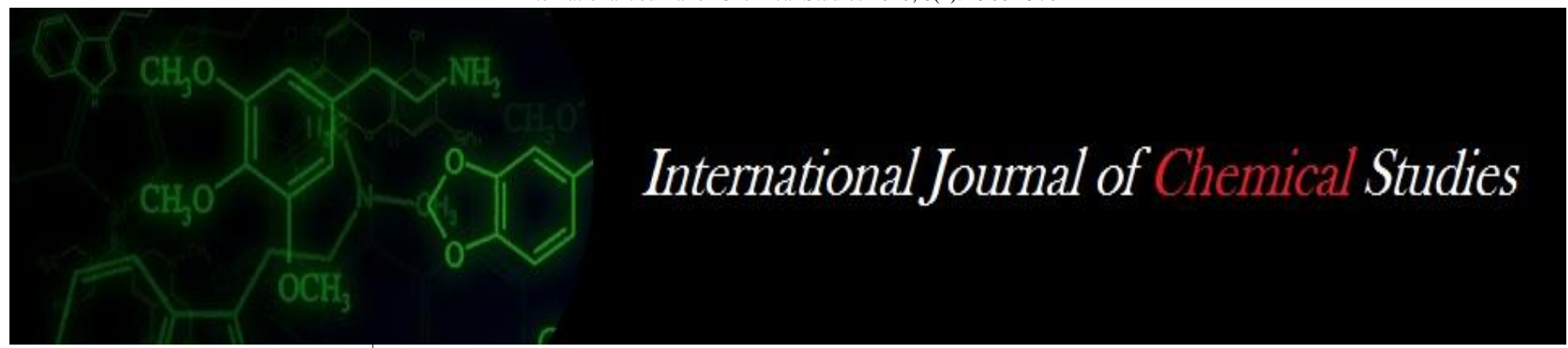

P-ISSN: 2349-8528

E-ISSN: 2321-4902

www.chemijournal.com

IJCS 2020; 8(4): 1966-1970

(C) 2020 IJCS

Received: 06-05-2020

Accepted: 08-06-2020

Sunil Mahnoori

Division of Food Science and

Technology, Main Campus

Chatha, SKUAST-Jammu and

Kashmir, India

Jagmohan Singh

Division of Food Science and

Technology, Main Campus

Chatha, SKUAST-Jammu and

Kashmir, India

Neeraj Gupta

Division of Food Science and

Technology, Main Campus

Chatha, SKUAST-Jammu and

Kashmir, India
Corresponding Author: Jagmohan Singh

Division of Food Science and

Technology, Main Campus

Chatha, SKUAST-Jammu and

Kashmir, India

\section{Studies on processing and storage stability of litchi - beetroot blended RTS beverage}

\author{
Sunil Mahnoori, Jagmohan Singh and Neeraj Gupta
}

DOI: https://doi.org/10.22271/chemi.2020.v8.i4u.9915

\begin{abstract}
An experiment was carried out to study blended litchi-beetroot juice for the preparation of RTS beverage. In the present study, the litchi and beetroot juice were blended in the ratios of 100:00, 95:05, 90:10, $85: 15,80: 20,75: 25,70: 30$ for the preparation of ready to serve beverage as per FPO specifications. The processed products were stored at ambient conditions and subjected to chemical and sensory evaluation at an interval of 30 days for a period of 90 days. With the advancement of storage, an increasing trend was observed in reducing sugar and total sugar whereas ascorbic acid, anthocyanin, phosphorus and iron showed a decreasing trend. After three months of storage, sensory evaluation revealed that the treatment $\mathrm{T}_{6}$ recorded the highest score for overall acceptability.
\end{abstract}

Keywords: Litchi, beetroot, processing, blended, ready to serve

\section{Introduction}

The litchi (Litchi chinensis Sonn.) is the most important sub-tropical evergreen fruit tree and belongs to the family Sapindaceae. It is highly prized fruit both in its fresh and preserved forms. India is the second largest producer of litchi in the world after china. It is grown in the states of Bihar, Tripura, West Bengal, Uttar Pradesh, Punjab and Haryana (Bhandari et al. 2018) ${ }^{[4]}$. It is well estimated that out of the total fruit harvested during the short peak season (May-June) more than $30 \%$ fruits (1.68 lac metric tonnes) are spoiled in the way of transportation and marketing due to more perishable, delicate and poor storage quality. The Litchi fruit contains 60 per cent juice, 8 per cent rag, 19 per cent seed and 13 per cent skin varying with climate and variety. It is also an excellent source of vitamin C (40-90mg/100g) but contains insignificant amount of protein $(0.8-0.9 \%)$, pectin $(0.43 \%)$, fat $(0.3 \%)$ and minerals especially phosphorous and calcium $(0.7 \%)$. The fruit is small, conical, heart shaped or spherical in shape and bright red in colour. The litchi pulp has milky white colour and contains pleasant aroma and flavour which makes it suitable for blending with other juices to improve their acceptability and make use of available nutrients (Khan et al. 1988).

Beetroot (Beta vulgaris L.) having bright crimson colour also known as beet, chard, spinach beet, sea beet, garden beet, white beet and Chukander (in Hindi) belongs to Chenopodiaceae family. It is famous for its high valued juice and medicinal properties. The beetroot can be kept for 4-5 days when refrigerated in the vegetable crisper (Chibber et al. 2019) ${ }^{[5]}$. Beta vulgaris roots contain significant amounts of vitamin $C$, whilst the leaves are an excellent source of vitamin A. It is among the sweetest of vegetables, containing more sugar even than carrots or sweet corn. Incorporation of beetroot in the juice, which contains considerable amount of nitrate helps to dilate and widen the blood vessels, thereby reducing the blood pressure and allowing more blood flow and it can also be effective to boost the athletes' performance (Lansley et al. 2011) ${ }^{[13]}$. Muddy flavour in fresh beetroot juice is due to presence of geosmin. A small increase in the habitual consumption of antioxidant and polyphenol-rich beverages such as beetroot juices blended with litchi juice may have significant positive effect on public health (Mahnoori et al. 2020a) ${ }^{[14]}$. Juice blending is one of the best methods to improve the nutritional quality of the juice. Thus blending of litchi and beetroot juice offers many opportunities to develop balanced health product high in quality with respect to both sensory and nutritional aspects. 


\section{Material and methods}

The defected and injured fruits of litchi and beetroot were sorted out and healthy ones for retained for extraction of juice. The litchi and the beetroot juice were blended with each other in different ratios for developing RTS i,e $\mathrm{T}_{1}$ : 100:00, $\mathrm{T}_{2}: 95: 05, \mathrm{~T}_{3}: 90: 10, \mathrm{~T}_{4}: 85: 15, \mathrm{~T}_{5}: 80: 20, \mathrm{~T}_{6}: 75: 25, \mathrm{~T}_{7}: 70: 30$. The desired quantity of sugar and citric acid was added in warm water and the solution is strained through muslin cloth. The solution is added in litchi-beetroot blend so as to maintain its total soluble solids and acidity of the blended RTS. Litchibeetroot blended ready to serve beverage was packed in presterilized $200 \mathrm{ml}$ glass bottles. The bottles were then sealed air tight, pasteurized, labelled and stored at a cool and dry place. The RTS was stored at ambient condition to study the storage behaviour of the product with respect to the changes in chemical and sensory qualities during storage. The product was evaluated immediately after preparation and then at an interval of 30 days up to 90 days of storage. Reducing sugar, total sugar and anthocyanin were determined as per the method suggested by Ranganna (1994) ${ }^{[17]}$, ascorbic acid (AOAC, 2000) ${ }^{[2]}$ phosphorus and iron content (Singh et al. 1999) ${ }^{[20]}$. The samples were evaluated on the basis of sensory evaluation by semi-trained taste panels of 6-7 judges using 9 point hedonic scale. A score of 5.5 and above was considered acceptable (Amerine et al. 1965) ${ }^{[1]}$. The lab experiment was carried out in completely randomized design with factorial concept for the interpretation of results through analysis of variance (Gomez and Gomez, 1984) ${ }^{[8]}$.

\section{Results and discussion \\ Reducing Sugar}

The data pertaining to reducing sugar content of different treatments in Table-1 depicted a significant increase in reducing sugar content during storage. At initial day the highest value of reducing sugar 5.64 per cent was recorded in treatment $T_{1}(100: 0:$ :litchi:beetroot) followed by 5.57 per cent in treatment $T_{2}(95: 05:$ :litchi: beetroot). After 90 days of storage period, treatment $T_{1}(100: 0::$ litchi: beetroot) recorded highest value of 5.87 per cent followed by treatment $\mathrm{T}_{2}$ (95:05::litchi: beetroot) with reducing sugar content of 5.80 per cent. The reducing sugar content of RTS (ready to serve) beverage increased significantly with increase in storage period. On the basis of treatment mean values, it was observed that reducing sugars of 5.75 per cent were the highest in treatment $T_{1}(100: 0::$ litchi: beetroot $)$ and lowest of 5.30 per cent in treatment $\mathrm{T}_{7}(70: 30:$ :litchi: beetroot $)$. It is also clear from the table that interaction between treatments and storage period was significant in respect of reducing sugar. The mean values of storage period showed an increase from initial value of 5.39 to 5.65 per cent during 90 days of storage. The slight increase in reducing sugars might be due to the result of inversion of non- reducing sugars into reducing sugars. Increase in reducing sugars content during storage of RTS beverage prepared from guava papaya blends have been reported by Tiwari (2000) ${ }^{[22]}$. Similar findings have also been reported by Sharma and Singh (2005) ${ }^{[19]}$ in lime juice and Gupta (2019) ${ }^{[9]}$ in karonda-beetroot RTS beverage.

Table 1: Effect of treatments and storage period on reducing sugar (\%) of litchi beetroot blended RTS beverage

\begin{tabular}{|c|c|c|c|c|c|}
\hline \multirow{2}{*}{ Treatments } & \multicolumn{4}{|c|}{ Storage period (days) } \\
\cline { 2 - 6 } & $\mathbf{0}$ & $\mathbf{3 0}$ & $\mathbf{6 0}$ & $\mathbf{9 0}$ & Mean \\
\hline $\mathrm{T}_{1}(100: 0::$ litchi: Beetroot $)$ & 5.64 & 5.71 & 5.79 & 5.87 & 5.75 \\
\hline $\mathrm{T}_{2}(95: 05::$ Litchi: Beetroot $)$ & 5.57 & 5.63 & 5.70 & 5.80 & 5.67 \\
\hline $\mathrm{T}_{3}(90: 10::$ Litchi: Beetroot $)$ & 5.46 & 5.55 & 5.65 & 5.75 & 5.60 \\
\hline
\end{tabular}

\begin{tabular}{|c|c|c|c|c|c|}
\hline $\mathrm{T}_{4}(85: 15::$ Litchi: Beetroot $)$ & 5.40 & 5.48 & 5.59 & 5.67 & 5.53 \\
\hline $\mathrm{T}_{5}$ (80:20 :: Litchi: Beetroot) & 5.31 & 5.39 & 5.47 & 5.56 & 5.43 \\
\hline $\mathrm{T}_{6}(75: 25::$ Litchi: Beetroot $)$ & 5.24 & 5.31 & 5.39 & 5.48 & 5.35 \\
\hline $\mathrm{T}_{7}(70: 30$ ::Litchi: Beetroot) & 5.17 & 5.28 & 5.36 & 5.42 & 5.30 \\
\hline Mean & 5.39 & 5.47 & 5.56 & 5.65 & \\
\hline Factors & \multicolumn{5}{|c|}{ C.D.(P=0.05) } \\
\hline Treatment (A) & \multicolumn{5}{|c|}{0.01} \\
\hline Storage $(\mathrm{B})$ & \multicolumn{5}{|c|}{0.02} \\
\hline Treatment X Storage (A X B) & \multicolumn{5}{|c|}{ N.S. } \\
\hline
\end{tabular}

\section{Total sugar}

It is evident from Table-2 that treatments significantly influenced the total sugar content of RTS (ready to serve) beverage. Among the treatments, treatment $\mathrm{T}_{1}$ (100:00::litchi:beetroot) recorded the highest value of total sugars 13.05 per cent followed by treatment $\mathrm{T}_{2}$ (95:05::litchi: beetroot) with total sugar content of 12.95 per cent at initial day. After 90 days of storage, treatment $\mathrm{T}_{1}(100: 00$ ::litchi: beetroot) recorded highest value of 13.61 per cent followed by $\mathrm{T}_{2}$ (95:05::litchi: beetroot) having total sugar content of 13.55 per cent. The maximum mean value of total sugar content of 13.30 per cent was recorded in treatment $T_{1}(100: 00:$ :litchi: beetroot) and the lowest mean value of total sugar content of 12.67 per cent was recorded in $T_{7}$ (70:30::litchi: beetroot). Significant increase in total sugar content was observed with the progress in storage period. The mean values of storage period showed an increase from initial value of 12.72 to 13.29 per cent during 90 days of storage. The slight increase in total sugars might be due to conversion of polysaccharides into monosaccharides. The increase might also be attributed to hydrolysis of starch in to sugars. Similar observations were made by Tandon et al. (2007) ${ }^{[21]}$ in guava-aonla blended RTS beverage, Pangotra et al. $2019^{[16]}$ in phalsa-pear blended crush and Sharma et al. $2017^{[18]}$ in Jamun-mango RTS beverage.

Table 2: Effect of treatments and storage period on total sugar (\%) of litchi-beetroot blended RTS beverage

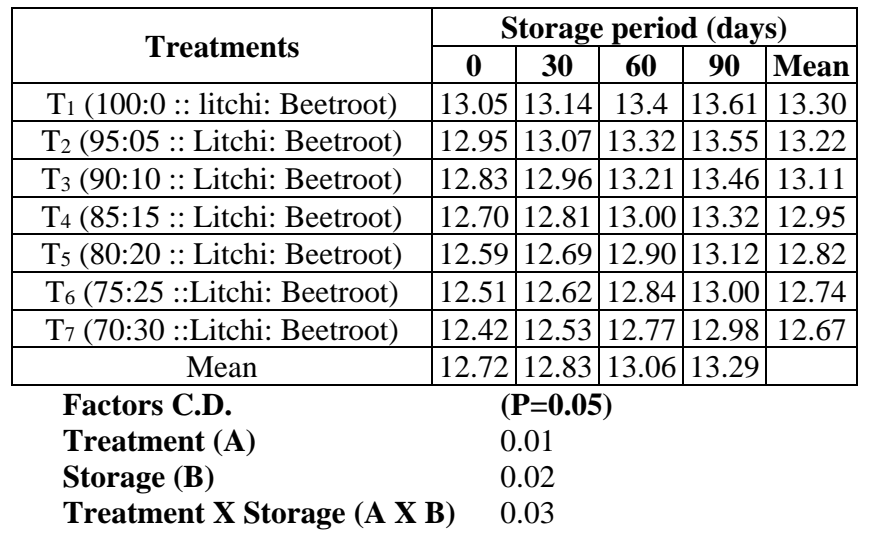

\section{Ascorbic acid}

The data presented in Table-3 showed the effect of various treatments and storage period on ascorbic acid content of litchi-beetroot blended RTS (ready to serve) beverage. The data revealed that treatments significantly influenced the ascorbic acid content of litchi-beetroot blended RTS (ready to serve) beverage. At initial day of storage, the highest ascorbic acid content of $(6.21 \mathrm{mg} / 100 \mathrm{ml})$ was recorded in treatment $\mathrm{T}_{1}$ (100:0::litchi: beetroot) and lowest $(5.89 \mathrm{mg} / 100 \mathrm{ml})$ in treatment $\mathrm{T}_{7}$ (70:30::litchi: beetroot). The values decreased to $(5.34 \mathrm{mg} / 100 \mathrm{ml})$ in $\mathrm{T}_{1}(100: 0::$ litchi: beetroot $)$ and $(5.10$ $\mathrm{mg} / 100 \mathrm{~g})$ in $\mathrm{T}_{7}$ (70:30::litchi:beetroot) after 90 days of storage. Overall mean highest ascorbic acid content (5.67 
$\mathrm{mg} / 100 \mathrm{ml})$ was recorded in treatment $\mathrm{T}_{1}(100: 0$ : :litchi: beetroot) and lowest $(5.41 \mathrm{mg} / 100 \mathrm{ml})$ was recorded in treatment $\mathrm{T}_{7}$ (70:30::litchi: beetroot).. The mean values of storage period showed a decreasing trend from initial value of 6.04 to $5.21(\mathrm{mg} / 100 \mathrm{ml})$ after 90 days of storage. The decline in ascorbic acid during storage of the product might be due to the effect of temperature during the storage and greater catalytic activity of fructose in the catabolization of vitamin ' $C$ '. Similar results were reported that ascorbic acid content decreased during three months of storage in Dhiman et al. $2017^{[6]}$.

Table 3: Effect of treatments and storage period on ascorbic acid $(\mathrm{mg} / 100 \mathrm{ml})$ of litchi-beetroot blended RTS beverage

\begin{tabular}{|c|c|c|c|c|c|}
\hline \multirow{2}{*}{ Treatments } & \multicolumn{5}{|c|}{ Storage period (days) } \\
\hline & $\mathbf{0}$ & 30 & 60 & 90 & Mean \\
\hline $\mathrm{T}_{1}(100: 0$ :: litchi: Beetroot) & 6.21 & 5.61 & 5.55 & 5.34 & 5.67 \\
\hline $\mathrm{T}_{2}$ (95:05 :: Litchi: Beetroot) & 6.16 & 5.57 & 5.46 & 5.28 & 5.61 \\
\hline $\mathrm{T}_{3}(90: 10::$ Litchi: Beetroot) & 6.11 & 5.60 & 5.44 & 5.24 & 5.59 \\
\hline $\mathrm{T}_{4}(85: 15::$ Litchi: Beetroot $)$ & 6.04 & 5.54 & 5.32 & 5.16 & 5.51 \\
\hline $\mathrm{T}_{5}$ (80:20 :: Litchi: Beetroot) & 5.97 & 5.44 & 5.30 & 5.18 & 5.47 \\
\hline $\mathrm{T}_{6}(75: 25$ ::Litchi: Beetroot) & 5.92 & 5.41 & 5.31 & 5.20 & 5.46 \\
\hline $\mathrm{T}_{7}(70: 30$ ::Litchi: Beetroot) & 5.89 & 5.38 & 5.30 & 5.10 & 5.41 \\
\hline Mean & 6.04 & 5.50 & 5.38 & 5.21 & \\
\hline Fac & \multicolumn{5}{|c|}{ C.D. $(P=0.05)$} \\
\hline Treatment (A) & \multicolumn{5}{|c|}{0.01} \\
\hline Storage (B) & \multicolumn{5}{|c|}{0.01} \\
\hline Treatment X Storage (A X B) & \multicolumn{5}{|c|}{0.033} \\
\hline
\end{tabular}

\section{Anthocyanin}

A perusal of data in Table-4 showed the anthocyanin was significantly affected by treatments and storage durations. Among treatments, $\mathrm{T}_{1}$ (100:0::litchi: beetroot) had maximum anthocyanin of $9.00(\mathrm{mg} / 100 \mathrm{ml})$ however, the lowest anthocyanin content of $6.15(\mathrm{mg} / 100 \mathrm{ml})$ was noticed in treatment $\mathrm{T}_{7}$ (70:30::litchi: beetroot) at initial day of storage. Maximum mean treatment values of anthocyanin content of 8.48 ( $\mathrm{mg} / 100 \mathrm{ml})$ was recorded in $\mathrm{T}_{1}$ (100:00::litchi: beetroot) and minimum mean treatment values of anthocyanin content of 5.74 in $\mathrm{T}_{7}$ (70:30::litchi: beetroot). Anthocyanin content was significantly affected by storage period which follows the decreasing trend. The mean values of storage period showed a decreasing trend from initial value of 7.56 to $6.59(\mathrm{mg} / 100$ $\mathrm{ml}$ ) after 90 days of storage period. Bafna (2014) ${ }^{[3]}$ reported 19.66 percent decrease in anthocyanin content in case of ready to serve beverage prepared from kokam juice. Kapoor and Ranote (2015) ${ }^{[10]}$ while studying antioxidant potentials and quality of blended pear-jamun juice reported decrease in anthocyanin content during storage.

Table 4: Effect of treatments and storage period on total anthocyanin $(\mathrm{mg} / 100 \mathrm{ml})$ of litchi-beetroot blended RTS beverage

\begin{tabular}{|c|c|c|c|c|c|}
\hline \multirow{2}{*}{ Treatments } & \multicolumn{5}{|c|}{ Storage period (days) } \\
\hline & $\mathbf{0}$ & 30 & 60 & 90 & Mean \\
\hline $\mathrm{T}_{1}(100: 0::$ litchi: Beetroot) & 9.0 & 8.55 & 8.30 & 8.05 & 8.48 \\
\hline $\mathrm{T}_{2}$ (95:05:: Litchi: Beetroot) & 8.55 & 8.30 & 7.90 & 7.50 & 8.06 \\
\hline $\mathrm{T}_{3}(90: 10::$ Litchi: Beetroot) & 8.05 & 7.60 & 7.35 & 7.10 & 7.52 \\
\hline $\mathrm{T}_{4}(85: 15::$ Litchi: Beetroot) & 7.55 & 7.25 & 6.10 & 6.55 & 6.86 \\
\hline $\mathrm{T}_{5}(80: 20$ :: Litchi: Beetroot) & 7.10 & 6.80 & 6.55 & 6.15 & 6.65 \\
\hline $\mathrm{T}_{6}(75: 25$ ::Litchi: Beetroot) & 6.54 & 6.35 & 6.10 & 5.50 & 6.12 \\
\hline T7 (70:30 ::Litchi: Beetroot) & 6.15 & 6.0 & 5.55 & 5.25 & 5.74 \\
\hline Mean & 7.56 & 7.26 & 6.84 & 6.59 & \\
\hline Factors & \multicolumn{5}{|c|}{ C.D. $(P=0.05)$} \\
\hline Treatment (A) & \multicolumn{5}{|c|}{0.01} \\
\hline Storage $(\mathrm{B})$ & \multicolumn{5}{|c|}{0.02} \\
\hline Treatment X Storage (A X B) & \multicolumn{5}{|c|}{0.03} \\
\hline
\end{tabular}

\section{Phosphorus content}

The data presented in Table-5 showed the effect of various treatments and storage period on phosphorous content of litchi-beetroot blended RTS (ready to serve) beverage. The data revealed that treatments significantly influenced the phosphorous content of litchi-beetroot blended RTS (ready to serve) beverage. At initial day of storage, the highest phosphorous content of $(2.90 \mathrm{mg} / 100 \mathrm{ml})$ was recorded in treatment $\mathrm{T}_{7}$ (100:0::litchi: beetroot) followed by $\mathrm{T}_{6}$ (95:05::litchi: beetroot) and lowest $(2.10 \mathrm{mg} / 100 \mathrm{ml})$ in treatment $T_{1}(100: 0::$ litchi: beetroot). After 90 days of storage the values decreased to $(2.40 \mathrm{mg} / 100 \mathrm{~g})$ in $\mathrm{T}_{7}$ (70:30::litchi: beetroot) and $(1.75 \mathrm{mg} / 100 \mathrm{ml})$ in $\mathrm{T}_{1}(100: 0:$ :litchi: beetroot). Phosphorous content was significantly affected by storage period. The mean values of storage period showed a decreasing trend from initial value of 2.54 to $2.07(\mathrm{mg} / 100 \mathrm{ml})$ after 90 days of storage. The decrease could be due to chemical interaction between the organic constituents of the juice induced by temperature and action of enzymes. Kumar et al. (2012) ${ }^{[12]}$ observed reduction in the minerals of guava blended ready-to-serve beverage and nectar at the end of 120 days of storage.

Table 5: Effect of treatments and storage period on phosphorous $(\mathrm{mg} / 100 \mathrm{ml})$ of litchi-beetroot blended RTS beverage

\begin{tabular}{|l|c|c|c|c|c|}
\hline \multirow{2}{*}{ Treatments } & \multicolumn{5}{|c|}{ Storage period (days) } \\
\cline { 2 - 6 } & $\mathbf{0}$ & $\mathbf{3 0}$ & $\mathbf{6 0}$ & $\mathbf{9 0}$ & Mean \\
\hline $\mathrm{T}_{1}(100: 0::$ litchi: Beetroot $)$ & 2.10 & 2.00 & 1.85 & 1.75 & 1.93 \\
\hline $\mathrm{T}_{2}(95: 05::$ Litchi: Beetroot $)$ & 2.30 & 2.15 & 2.05 & 1.90 & 2.10 \\
\hline $\mathrm{T}_{3}(90: 10::$ Litchi: Beetroot $)$ & 2.40 & 2.20 & 2.10 & 1.95 & 2.16 \\
\hline $\mathrm{T}_{4}(85: 15::$ Litchi: Beetroot) & 2.55 & 2.35 & 2.20 & 2.05 & 2.29 \\
\hline $\mathrm{T}_{5}(80: 20::$ Litchi: Beetroot $)$ & 2.70 & 2.50 & 2.35 & 2.15 & 2.42 \\
\hline $\mathrm{T}_{6}(75: 25::$ Litchi: Beetroot) & 2.85 & 2.65 & 2.50 & 2.35 & 2.59 \\
\hline $\mathrm{T}_{7}(70: 30::$ Litchi: Beetroot) & 2.90 & 2.70 & 2.55 & 2.40 & 2.64 \\
\hline \multicolumn{1}{|c|}{ Mean } & 2.54 & 2.36 & 2.22 & 2.07 & \\
\hline Factors $(\mathbf{P}=\mathbf{0 . 0 5})$ \\
Treatment (A) & 0.01 & & \\
Storage (B) & 0.02 & \\
Treatment X Storage (A X B) & 0.03 &
\end{tabular}

\section{Iron content}

The data presented in Table- 6 showed the effect of various treatments and storage period on iron content of litchibeetroot blended RTS (ready to serve) beverage. The data revealed that treatments significantly influenced the iron content of litchi-beetroot blended RTS beverage. At initial day of storage, the highest Iron content of $(0.12 \mathrm{mg} / 100 \mathrm{ml})$ was recorded in treatment $\mathrm{T}_{7}$ (100:0::litchi: beetroot) and lowest $(0.04 \mathrm{mg} / 100 \mathrm{ml})$ in treatment $\mathrm{T}_{1}(100: 0:$ :litchi: beetroot). After 90 days of storage the values decreased to $(0.08 \mathrm{mg} / 100 \mathrm{~g})$ in $\mathrm{T}_{7}(70: 30:$ :litchi: beetroot $)$ and $(0.02$ $\mathrm{mg} / 100 \mathrm{ml})$ in $\mathrm{T}_{1}(100: 0:$ :litchi: beetroot). Iron content was significantly affected by storage period. There was significant decrease in Iron content of litchi-beetroot blended RTS (ready to serve) beverage during 90 days of storage. The mean values of storage period showed a decreasing trend from initial value of 0.08 to $0.05(\mathrm{mg} / 100 \mathrm{ml})$ after 90 days of storage. The decrease could be due to chemical interaction between the organic constituents of the juice induced by temperature and action of enzymes. Similar findings have been observed by Mahnoori et al. 2020b ${ }^{[15]}$ in litchi-beetroot blended leather. 
Table 6: Effect of treatments and storage period on iron content $(\mathrm{mg} / 100 \mathrm{ml})$ of litchi - beetroot blended RTS beverage

\begin{tabular}{|c|c|c|c|c|c|}
\hline \multirow{2}{*}{ Treatments } & \multicolumn{5}{|c|}{ Storage period (days) } \\
\hline & $\mathbf{0}$ & 30 & 60 & 90 & Mean \\
\hline $\mathrm{T}_{1}(100: 0::$ litchi: Beetroot) & 0.04 & 0.03 & 0.03 & 0.02 & 0.03 \\
\hline $\mathrm{T}_{2}(95: 05::$ Litchi: Beetroot) & 0.05 & 0.05 & 0.04 & 0.03 & 0.04 \\
\hline $\mathrm{T}_{3}(90: 10::$ Litchi: Beetroot) & 0.06 & 0.05 & 0.05 & 0.04 & 0.05 \\
\hline $\mathrm{T}_{4}(85: 15::$ Litchi: Beetroot) & 0.07 & 0.07 & 0.06 & 0.05 & 0.06 \\
\hline $\mathrm{T}_{5}(80: 20$ :: Litchi: Beetroot) & 0.09 & 0.08 & 0.07 & 0.06 & 0.07 \\
\hline $\mathrm{T}_{6}(75: 25::$ Litchi: Beetroot $)$ & 0.10 & 0.09 & 0.07 & 0.06 & 0.08 \\
\hline $\mathrm{T}_{7}(70: 30$ ::Litchi: Beetroot) & 0.12 & 0.10 & 0.09 & 0.08 & 0.09 \\
\hline Mean & 0.08 & 0.07 & 0.06 & 0.05 & \\
\hline Factors & & D. $(\mathbf{P}=1$ & $0.05)$ & & \\
\hline Treatment (A) & 0.0 & & & & \\
\hline Storage (B) & 0.0 & & & & \\
\hline Treatment X Storage (A X B) & 0.0 & & & & \\
\hline
\end{tabular}

\section{Overall acceptability}

Table-7 pertaining to score of overall acceptability revealed that at initial day, the highest score of 8.53 was recorded in treatment $\mathrm{T}_{6}$ (75:25::litchi: beetroot) followed by 8.00 in $\mathrm{T}_{5}$ (80:20::litchi: beetroot). After 90 days of storage the values decreased to 7.60 in treatment $\mathrm{T}_{6}(75: 25:$ :litchi: beetroot $)$ and 7.27 in $\mathrm{T}_{5}$ (80:20::litchi: beetroot). The mean value of treatments varied significantly and the highest mean score of 8.03 was assigned to $T_{6}(75: 25::$ litchi: beetroot) followed by $\mathrm{T}_{5}$ (80:20::litchi: beetroot).During storage period, there was significant decrease in mean score from 7.75 at initial day to 6.91 at the end of 90 days of storage period. The effect of interaction between treatment and storage period was found to differ significantly at $5 \%$ level of significance. The decrease in overall acceptability scores in products may be due to reduction of $\mathrm{SO}_{2}$ content resulting in non-enzymatic browning to some extent, change in chemical composition of the product and loss of colour and flavour during storage period of 90 days Similar observations of decrease in overall acceptability score was reported by Gehlot et al. (2009) ${ }^{[7]}$ in bael mango beverage.

Table 7: Effect of treatments and storage period on mean score evaluation of overall acceptability of litchi-beetroot blended RTS beverage

\begin{tabular}{|l|c|c|c|c|c|}
\hline \multirow{2}{*}{ Treatments } & \multicolumn{5}{|c|}{ Storage period (days) } \\
\cline { 2 - 7 } & $\mathbf{0}$ & $\mathbf{3 0}$ & $\mathbf{6 0}$ & $\mathbf{9 0}$ & Mean \\
\hline $\mathrm{T}_{1}(100: 0::$ litchi: Beetroot) & 7.60 & 7.10 & 6.77 & 6.50 & 6.99 \\
\hline $\mathrm{T}_{2}(95: 05::$ Litchi: Beetroot $)$ & 7.13 & 6.97 & 6.60 & 6.43 & 6.78 \\
\hline $\mathrm{T}_{3}(90: 10::$ Litchi: Beetroot $)$ & 7.52 & 7.23 & 7.00 & 6.83 & 7.15 \\
\hline $\mathrm{T}_{4}(85: 15::$ Litchi: Beetroot) & 7.70 & 7.40 & 7.13 & 6.80 & 7.26 \\
\hline $\mathrm{T}_{5}(80: 20::$ Litchi: Beetroot) & 8.00 & 7.73 & 7.40 & 7.27 & 7.60 \\
\hline $\mathrm{T}_{6}(75: 25::$ Litchi: Beetroot) & 8.53 & 8.13 & 7.87 & 7.60 & 8.03 \\
\hline $\mathrm{T}_{7}(70: 30::$ Litchi: Beetroot) & 7.77 & 7.47 & 7.33 & 6.93 & 7.38 \\
\hline \multicolumn{1}{|c|}{ Mean } & 7.75 & 7.43 & 7.16 & 6.91 & \\
\hline Factors $(\mathbf{P}=\mathbf{0 . 0 5})$ \\
Treatment (A) & 0.01 \\
Storage (B) & 0.01 & \\
Treatment X Storage (A X B) & 0.03 &
\end{tabular}

\section{Conclusion}

On the basis of overall acceptability, it was found that treatment $T_{6}$ rated the best followed by treatment $T_{5}$.

\section{References}

1. Amerine MA, Pangborn RM, Roessler EB. Principle of sensory evaluation of food. Academic Press, New York and London, 1965.
2. AOAC. Official Methods of Analysis. 16th edn, Association of Official Analytical Chemists, Washington DC, 2000.

3. Bafna P. The best use of kokum (Garcinia indica) fruit as RTS beverage and fruit bar. International journal of nutrition and agricultural research. 2014; 1(1):1-9.

4. Bhandari A, Sharma A, Wali VK, Kour D. Effect of Mulching and Controlled Irrigation on On-Farm Crop Water Utilization and Quality of Litchi (Litchi chinensis Sonn.) cv. Dehradun. International Journal of Current Microbiology and Applied Sciences. 2018; 7(02):1-6.

5. Chibber AK, Singh J, Gupta N. Effect of humectants on mineral composition and microbial count of intermediate moisture beetroot (Beta vulgaris L.) cubes. Annals of Plant and Soil Research. 2019; 21(2):167-171.

6. Dhiman AK, Babu G, Attri S, Ramachandran P. Development and storage stability of pumpkin based ready to serve (RTS) beverage. The Bioscan. 2017; 12(3):1481-1486.

7. Gehlot P, Singh R, Siddiqui S. Development and evaluation bael mango ready to serve drink and squash. Haryana Journal of Horticultural Science. 2009; 38:3-4.

8. Gomez KA, Gomez AA. Statistical Procedures for Agricultural Research. 2nd edn, John Wiley and Sons, New York, 1984.

9. Gupta N. Studies on preparation of blended karonda-beet root ready to serve beverage. Indian Journal of Horticulture. 2019; 76(4):735-740.

10. Kapoor S, Ranote PS. Antioxidant potentials and quality of blended pear-jamun (Syzygium cumini L.) juice. International Research Journal of Biological Sciences. 2015; 4(4):30-37.

11. Khan A, Singh H, Krishna BR, Bhatia AK. Carotene enriched beverage. Indian Food Packer. 1988; 42:27-29.

12. Kumar SNS, Sreenivas KN, Shankarappa HT, Ravindra V. Standarization of receipe for value added nutraceutical beverages of guava blended with aloe vera and roselle. Environment and Ecology. 2012; 30(3B):995-1001.

13. Lansley KE, Winyard PG, Bailey SJ, Vanhatalo A, Wilkerson DP. Acute dietary nitrate supplementation improves cycling time trial performance. Mrd. Sci. Sports Exercise. 2011; 43:1125-1131.

14. Mahnoori S, Singh J, Gupta N. Preparation and evaluation of litchi and beetroot blended ready to serve beverage. The Pharma Innovation Journal. 2020a; 9(5):33-37.

15. Mahnoori S, Singh J, Gupta N. Standardization and preparation of litchi-beetroot blended leather. Journal of Pharmacognosy and Phytochemistry. 2020b; 9(3):454457.

16. Pangotra BB, Gupta N, Sharma A. Development of phalsa-pear blended crush and its quality evaluation during storage. Ann. Agric. Res. New Series. 2019; 40(4):1-8.

17. Ranganna S. Handbook of analysis and quality control of fruit and vegetable products, 2nd ed. Tata McGraw-Hill, New Delhi, India, 1994.

18. Sharma DS, Kaul RK, Sood M, Gupta N. Studies on stability and quality of Jamun-mango blended ready to serve beverage. Indian journal of Horticulture. 2017; 74(2):299-302.

19. Sharma A, Singh K. Effect of different treatments on TSS, sugars, viscosity and suspended pulp of lime juice during storage. Haryana journal of horticultural sciences. 2005; 34(1-2):45-46. 
20. Singh D, Chhonkar PK, Pandey RN. Soil plant water analysis. A method manual, Indian Agriculture Research Institute- New Delhi, 1999, 57-71.

21. Tandon DK, Kumar S, Dikshit A, Shukla DK. Storage study on bael-papaya blended RTS beverage. Indian Food Packer. 2007; 73:91-97.

22. Tiwari RB. Studies on blending of guava and papaya pulp for RTS beverages. Indian Food Packer, 2000; 54:68. 